\title{
The revolution and evolution of mechanical valves: The ball has left the cage
}

\author{
Sameer A. Hirji, MD, Tsuyoshi Kaneko, MD, and Sary Aranki, MD
}

\footnotetext{
From the Division of Cardiac Surgery, Department of Surgery, Brigham and Women's Hospital, Harvard Medical School, Boston, Mass.

Disclosures: Authors have nothing to disclose with regard to commercial support.

Received for publication Dec 28, 2017; accepted for publication Jan 9, 2018; available ahead of print March 7 , 2018.

Address for reprints: Sary Aranki, MD, Division of Cardiac Surgery, Brigham and Women's Hospital, 75 Francis

St, Boston, MA 02115 (E-mail: saranki@ partners.org).

J Thorac Cardiovasc Surg 2018;155:e149-50

$0022-5223 / \$ 36.00$

Copyright (c) 2018 by The American Association for Thoracic Surgery

https://doi.org/10.1016/j.jtcvs.2018.01.009
}

Significant advances have been made during the last half century in the design of mechanical valves. The 1960s, especially, was a significant period in terms of valve innovation and development. Ball valves were first implanted in the descending thoracic aorta by Hufnagel and colleagues (circa 1950s). ${ }^{1}$ Harken and colleagues ${ }^{2}$ later, in the early 1960 s, implanted the caged ball valve in a subcoronary position. It was not, however, until a retired pump engineer, Miles Edwards, and a young cardiac surgeon, Albert Starr, designed the StarrEdwards (SE) ball-in-a-cage mitral valve (MV), with promising initial results. ${ }^{3}$ SE MV design initially began with the poly(methyl methacrylate) cage design and was later refined into the cobalt-chromium alloy cage design with clothcovered valve orifice and bare metal struts. Valve design and development progressed remarkably with the advent of the tilting single-disc design to the contemporary bileaflet design, which led to the extinction of the SE valves after discontinuation of their production in 2007.

In this issue of the Journal, Battaglia and colleagues ${ }^{4}$ report an interesting case of a patient whose SE MV had been implanted 42 years previously (1974) for rheumatic mitral stenosis. Impressively, the patient denied any significant thrombotic or hemorrhagic complications and had only had dyspnea and fatigue develop 2 years previously. Transthoracic echocardiography showed mildly elevated transvalvular gradients with early-onset pulmonary hypertension, tricuspid regurgitation, and right heart dysfunction. At surgery, extensive pannus formation and mitral annular calcification were noted, which necessitated decalcification. Replacement of the SE valve with a $25-\mathrm{mm}$ bileaflet valve, concomitant biatrial cryomaze, and tricuspid repair with a 27-mm Duran band (Medtronic Inc, Minneapolis, Minn) was performed. The patient demonstrated extreme diligence in managing her anticoagulation, which also likely helped to avoid any hemorrhagic and thromboembolic complications such as are often reported with the SE MV. ${ }^{5-8}$

More than half a million SE valves were implanted globally between 1960 and 2007, with 300,000 implanted during

\section{References}

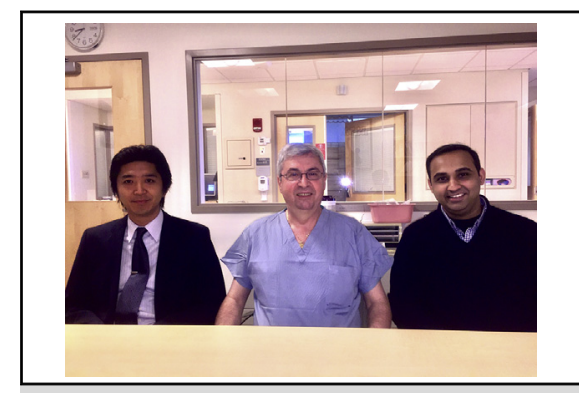

Tsuyoshi Kaneko, MD (left), Sary Aranki, MD (center) and Sameer A. Hirji, MD (right)

\section{Central Message}

The engineering prowess and creativity with the Starr-Edwards mitral valve has been revolutionary. In many ways, it ushered the modern era of valve surgery.

See Article page e147.

the last 7 years of its production (company data). Although lower survivals at 30 years with the SE valves have been reported, recent case reports have demonstrated durability beyond 30 and even 40 years. ${ }^{5-8}$ The observation that many patients still have these valves warrants accurate assessment by clinicians caring for these patients. Accurate assessment of pressure gradients across an SE valve is difficult because of the unique (noncentral) flow pattern. Likewise, pannus formation is challenging to visualize on transthoracic echocardiography, ${ }^{9}$ which may also influence treatment decisions. Timing of reoperative mitral surgery in the setting of SE MVs, although arguable, should be based on coexisting symptoms of pulmonary hypertension or right heart failure.

Can the ball-in-a-cage valve make a comeback? This is very doubtful for surgical implants. Perhaps one day, however, a catheter-based mechanical valve may be based on a cage design with a collapsible ball that could be deployed percutaneously. After all, who would have imagined 10 years ago that bioprosthetic transcatheter valve replacement would become an established reality? For now, it is safe to say that the ball has left the cage.

1. Gott VL, Alejo DE, Cameron DE. Mechanical heart valves: 50 years of evolution. Ann Thorac Surg. 2003;76:S2230-9.

2. Harken DE, Taylor WJ, Lefemine AA, Lunzer S, Low HB, Cohen ML, et al. Aortic valve replacement with a caged ball valve. Am J Cardiol. 1962;9:292-9.

3. Starr A, Edwards ML. Mitral replacement: clinical experience with a ball-valve prosthesis. Ann Surg. 1961;154:726-40. 
4. Battaglia F, Mielniczuk L, Dupuis J, Chan V. Explant of a ball and cage valve 42 years after initial implant. J Thorac Cardiovasc Surg. 2018; 155:e147-8.

5. Gödje OL, Fischlein T, Adelhard K, Nollert G, Klinner W, Reichart B. Thirty-year results of Starr-Edwards prostheses in the aortic and mitral position. Ann Thorac Surg. 1997:63:613-9.

6. Azuma S, Morita M, Yoshii Y, Mieno S. A case of the Starr-Edwards ball valve (model 6120) in the mitral position for 45 years. Gen Thorac Cardiovasc Surg. 2015;63:109-11.
7. Abad C, Hernández-Ramírez JM, Caballero E. Patient lives almost 50 years after aortic valve replacement with a Starr-Edwards caged-ball valve. Tex Heart Inst J. 2016;43:562.

8. Santoro G, Scognamiglio G, Gaio G, Iacono C, Giugno L, Russo MG. Transcatheter treatment of Starr-Edwards paravalvular leaks. J Cardiovasc Med (Hagerstown). 2016;17(Suppl 2):e218-20.

9. Hayatsu Y, Saito T, Adachi O, Kumagai K, Akiyama M, Motoyoshi N, et al. Reoperation on a Starr-Edwards ball valve without structural deterioration. Gen Thorac Cardiovasc Surg. 2012;60:827-9. 